\title{
Zika virus: - a review of the main aspects of this type of arbovirosis
}

\author{
Ítala Keane Rodrigues Dias[1], Cicera Luciana da Silva Sobreira ${ }^{[1]}$, \\ Rosa Maria Grangeiro Martins ${ }^{[2]}$, Kelly Fernanda Silva Santana ${ }^{[1]}$, \\ Maria do Socorro Vieira Lopes ${ }^{[3]}$, Emanuella Silva Joventino ${ }^{[4]}$ \\ and Maria Corina Amaral Viana ${ }^{[3]}$
}

\begin{abstract}
[1]. Programa de Pós-Graduação Stricto Sensu em Enfermagem, Universidade Regional do Cariri, Crato, CE, Brasil. [2]. Programa de Pós-Graduação Stricto Sensu em Saúde da Família, Universidade Regional do Cariri, Crato, CE, Brasil.

[3]. Departamento de Enfermagem, Universidade Regional do Cariri, Crato, CE, Brasil.

[4]. Departamento de Enfermagem, Universidade da Integração Internacional da Lusofonia Afro-Brasileira, Redenção, CE, Brasil.
\end{abstract}

\begin{abstract}
The objective of this study was to integrate findings related to Zika virus from the scientific literature. An integrative review of Medline was conducted, and data search was performed using the Health Sciences Descriptor Zika virus and the following filters: full texts available; studies in humans; full articles; and publications in Portuguese, French, English, and Spanish. After application of the filters, followed by reading of the titles, abstracts, and full texts, 44 studies were included in the review, for which content analysis was performed. A large part of the literature comprised review articles $(84 \% ; \mathrm{N}=37)$; the majority was in English (95\%, N=42). In 2016, 84\% ( $\mathrm{N}=37$ ) of our sample articles was published, while in 2017, 16\% ( $\mathrm{N}=7$ ) was published. The main form of viral transmission was thorough the mosquito Aedes aegypti $(\mathrm{N}=30)$. In addition, sexual transmission $(\mathrm{N}=09)$, transmission through blood transfusion $(\mathrm{N}=16)$, vertical transmission $(\mathrm{N}=21)$ and transmission from occupational activities $(\mathrm{N}=03)$ occurred. It was possible to diagnose the disease by testing blood $(\mathrm{N}=22)$, urine $(\mathrm{N}=14)$, saliva $(\mathrm{N}=06)$, semen/sperm $(\mathrm{N}=03)$, cerebrospinal and amniotic fluid, and other tissues $(\mathrm{N}=02)$. Symptomatology occurred in 1-5 people $(\mathrm{N}=10)$ between 3 and 7 days after a mosquito bite $(\mathrm{N}=09)$. Complications observed were Guillain Barré syndrome $(\mathrm{N}=27)$; neurological Zika syndrome ( $\mathrm{N}=27)$; meningitis, meningoencephalitis, and myelitis $(\mathrm{N}=07)$; deaths and/or newborns $(\mathrm{N}=03)$. The review provides scientific evidence that contributes to the care, planning and implementation of public policies.
\end{abstract}

Keywords: Zika virus. Arbovirus infections. Tropical Medicine. Aedes. Public health.

\section{INTRODUCTION}

Zika virus (ZIKV) is an arbovirus that was first isolated from a rhesus monkey in the Zika forest of Uganda in 1947. The first human epidemic was recorded in 2007 in Yap, Federated States of Micronesia, Pacific region. The second epidemic dates back to October 2013, five years after the first epidemic occurred in French Polynesia, again in the same region. Subsequently, the virus spread to several countries ${ }^{1}$. In Brazil, the first autochthonous transmission occurred in the Northeastern region in $2015^{2,3}$.

ZIKV arrived in Brazil due to possible events involving foreign individuals. In the country, there is an existing history of epidemics by arboviruses that stems from both socioeconomic conditions and the predominantly tropical climate, extensive

Corresponding author: Enfa. Ítala Keane Rodrigues Dias e-mail: itala_keany@hotmail.com

Received 10 May 2018

Accepted 6 June 2018 forest areas, and marshy, closed, and caatinga regions. These types of environments contribute to the persistent proliferation of vectors (Aedes species) in urban environments, contributing to the dissemination of this ZIKV to other regions of Brazil ${ }^{4}$.

Subsequently, in 2016, the World Health Organization (WHO) declared the ZIKV infection to be a public health emergency of global importance owing to the association of this arbovirus with the occurrence of the congenital Zika syndrome, a condition in which children born by women infected during pregnancy presented with various degrees of nervous system commitments ${ }^{5,6}$.

Although the limited number of published studies on the short- and long-term impacts of ZIKV restricts us from highlighting its social impact, the studies are considered to be of substantial value. ZIKV has been affecting tourism and hampering commercial turnover. Disability due to the ZIKV is associated with lower education levels, higher unemployment status, and additional financial costs for families. The growing demand for proper health care and support services for users with neurological sequelae perpetuates the rooted poverty 
cycle and contributes to the strain put on the different levels of health care ${ }^{6,7}$.

While this scenario becomes worrying, other important issues of this viral infection, such as the modes of transmission, treatments, and complications, should be explored and disseminated to the population with the aim to clarify existing controversies on the topic ${ }^{2}$. In view of these concerns and in order to clarify the particularities regarding this arbovirus, this study aimed to integrate findings from the scientific literature regarding ZIKV infection.

\section{METHODS}

This review integrated findings from studies developed using different methods in a logical, rigorous, and systematic manner, which enables reviewers to consolidate results without affecting the epistemological affiliation of the included empirical studies ${ }^{8}$.

For this review, the following six steps were undertaken: 1) identification of research questions, 2) search of the literature, 3 ) categorization of studies, 4) evaluation of studies included in the review, 5) interpretation of results, and 6) presentation of results 9 .

In the first step, the following research questions were addressed. What are the transmission forms of ZIKV? How can the disease be diagnosed? What are the clinical manifestations? What are the complications? What are the forms of prevention? How can ZIKV infection be treated?

After posing the research questions, the Medical Literature Analysis and Retrieval System Online (Medline) was used as the source for data search because during the search, the Health Sciences Descriptor (DeCS) of the Virtual Health Library Zika virus appeared with a sufficient number of results to answer the research questions.

During the categorization of the studies, the following inclusion criteria were used through the filters available in the data source: full texts available electronically in Medline, human studies, studies published in the format of articles, and publications in Portuguese, French, English and Spanish.

We excluded studies that did not respond to the research questions, were repeated, letters to the reader, editorials, clinical cases, experience reports, theses, dissertations, manuals and publications unavailable free of charge.

Figure 1 describes the search results in the data source retrieved in February 2017, based on the use of DeCs Zika virus. According to Figure 1, when using the descriptor, a total of 1,721 publications were obtained. The first filter applied was available texts, which resulted in 1,357 publications, followed by the language filter, resulting in 1,335 publications.

Following the application of the last filter, a survey of the remaining publications was performed through reading the titles to select for those that may answer our research questions. Thus, 246 publications were selected to be explored in full by means of reading the abstracts. After this analysis, 202 were excluded, according to the exclusion criteria of the research. At the end, 44 publications were included in the integrative review, as shown in Figure 1.
After the inclusion of the publications, a thorough reading of the texts was done through content analysis in order to identify the answers to the research questions that guided the integrative review, aiming to compose the thematic categories presented in the results. To organize data collection, information extracted from the publications was organized in Microsoft Excel, using a validated and adapted instrument for this type of research ${ }^{10}$.

\section{RESULTS}

Forty-four studies were included in the review; $84 \%(\mathrm{~N}=37)$ of which were literature reviews, while $16 \%(\mathrm{~N}=7)$ had a quantitative approach. In terms of language, $95 \%(\mathrm{~N}=42)$ were in English and 5\% in Portuguese $(\mathrm{N}=1)$ and French $(\mathrm{N}=1)$. Regarding the year of publication, 84\% were published in 2016 $(\mathrm{N}=37)$ and $16 \%$ in $2017(\mathrm{~N}=7)$.

Table 1 presents a summary of the forms of transmission, diagnosis, and clinical manifestations of ZIKV. According to the results regarding ZIKV transmission, most publications $(\mathrm{N}=30)$ demonstrated that the bite of the Aedes aegypti mosquito is the main form of transmission. In addition, other species of Aedes can also be vectors of the virus $(\mathrm{N}=04)$. Other forms of transmissions observed were through the sexual route $(\mathrm{N}=09)$, blood transfusion $(\mathrm{N}=16)$, the vertical route from the placental or intrapartum barrier $(\mathrm{N}=21)$, by contact with saliva and in occupational activities $(\mathrm{N}=03)$.

Regarding the diagnosis of ZIKV infection, the virus can be detected in the blood $(\mathrm{N}=22)$; urine $(\mathrm{N}=14)$; saliva $(\mathrm{N}=06)$; semen $(\mathrm{N}=03)$; and cerebrospinal fluid, amniotic fluid, and other tissues $(\mathrm{N}=02)$. This type of arbovirosis can be diagnosed through various laboratory tests $(\mathrm{N}=14)$ according to Table 1.

Regarding the clinical manifestations of ZIKV infections, $80 \%$ of the cases are asymptomatic $(\mathrm{N}=10)$. In symptomatic cases, symptoms may appear between 3 and 7 days after the bite by the infected mosquito $(\mathrm{N}=09)$. Clinical manifestations are nonspecific, and the most frequent manifestations are: low fever $\left(<38^{\circ} \mathrm{C}\right)$, rash/pruritic rash, arthritis and/or arthralgia, myalgia, and non-purulent conjunctivitis $(\mathrm{N}=25)$.

Table 2 summarizes the complications, forms of prevention and treatment of ZIKV infection. Complications included the Guillain Barré syndrome (N=27), ZIKV-associated neurological syndrome $(\mathrm{N}=27)$; meningitis, meningoencephalitis, and myelitis $(\mathrm{N}=07)$; deaths; and/or newborns $(\mathrm{N}=03)$.

Regarding ZIKV prevention, the results showed, more frequently $(\mathrm{N}=16)$, the control of the Aedes aegypti mosquito. In addition, in areas with a risk of infection $(\mathrm{N}=14)$, the following are recommended: light and long clothing $(\mathrm{N}=14)$ and mosquito nets, air conditioning, screens on doors and windows $(\mathrm{N}=11)$.

For the prevention of sexual and vertical transmission, it is recommended to abstain from sexual intercourse or to use condoms in situations where there is a risk of transmission $(\mathrm{N}=16)$. Women with potential exposure to ZIKV are advised to wait at least 8 weeks from the onset of symptoms to conceive $(\mathrm{N}=09)$. The use of larvicides and insecticides was also investigated $(\mathrm{N}=7)$. Regarding transfusion transmission, blood donors who traveled to ZIKV transmission sites were advised to avoid blood donations for a period of 28 days $(\mathrm{N}=06)$. 

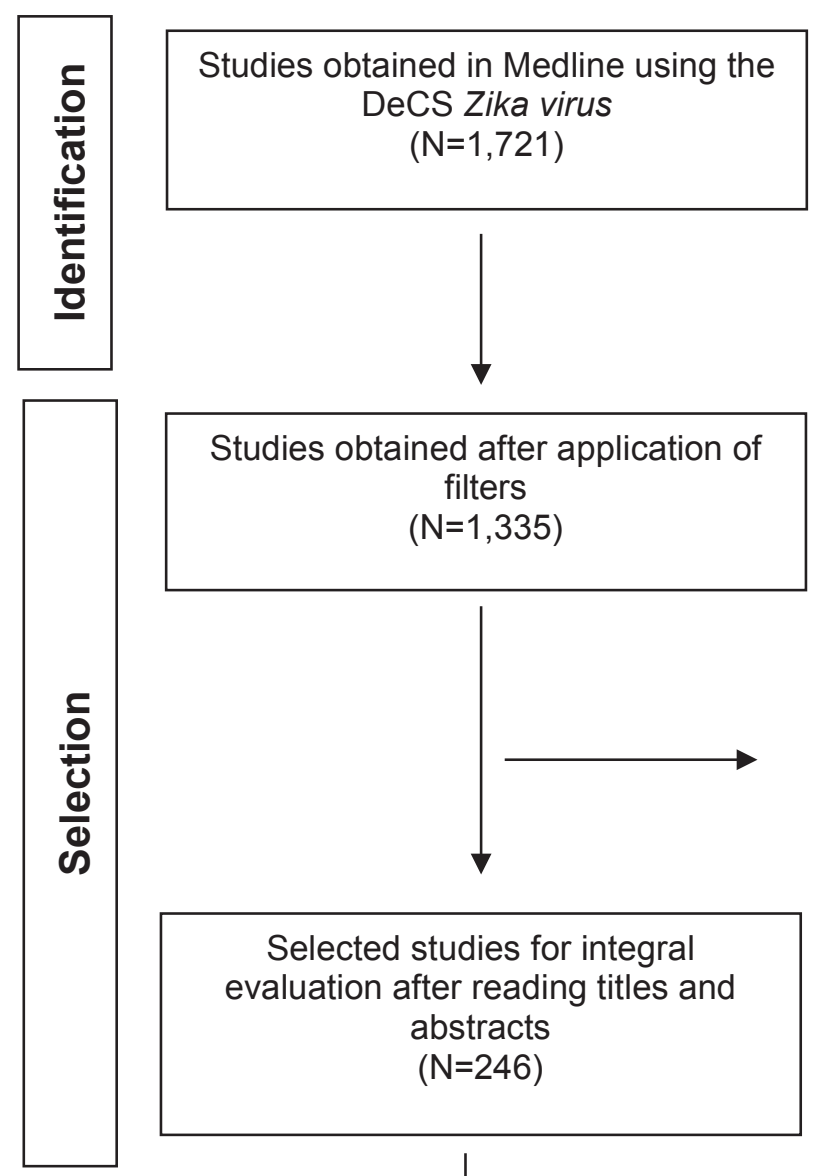

Studies obtained after application of filters

$(\mathrm{N}=1,335)$
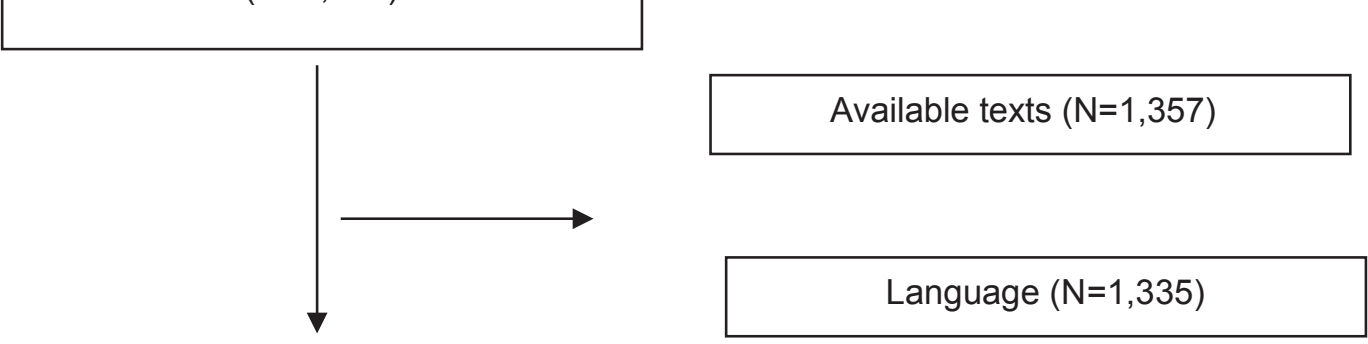

Selected studies for integral evaluation after reading titles and abstracts $(\mathrm{N}=246)$
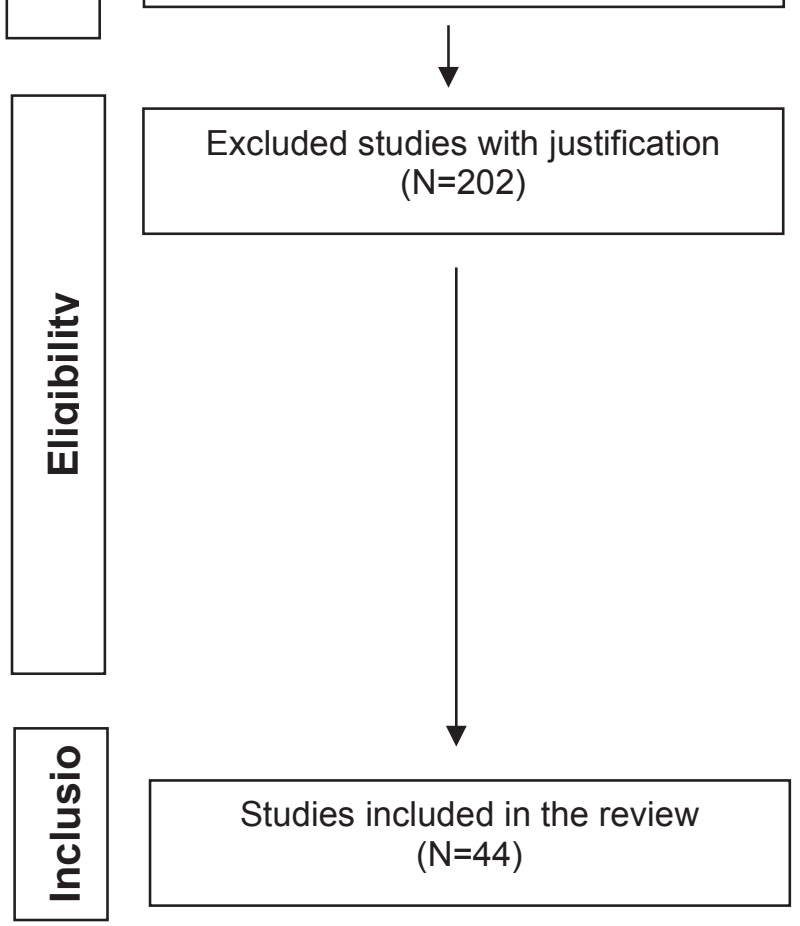

Not available for free $(\mathrm{N}=55)$, editorials $(\mathrm{N}=38)$, clinical cases $(\mathrm{N}=23)$, laboratory studies $(\mathrm{N}=21)$, epidemiological studies $(N=18)$, letters to the reader $(N=15)$, studies that did not meet the study objective ( $\mathrm{N}$ $=12)$, information notes $(\mathrm{N}=5)$, repeated $(\mathrm{N}=5)$, comments $(\mathrm{N}=3)$, clinical protocols $(\mathrm{N}=3)$, reflection texts $(\mathrm{N}=2)$, news $(\mathrm{N}=2)$.

FIGURE 1: Flowchart of the selection of integrative review studies. DeCS: descriptor. 




There is no specific treatment for ZIKV ( $\mathrm{N}=19)$. Thus, people with symptom manifestations should receive supportive treatment $(\mathrm{N}=14)$.

\section{DISCUSSION}

ZIKV is classified as a member of the Flaviviridae family, genus Flavivirus. ZIKV has the same general structure as other Flaviviruses. The virus is spherical with $42-52 \mathrm{~nm}$ in diameter. The envelope consists of a lipid bilayer with 180 units of $\mathrm{E}$ and $\mathrm{M}$ glycoproteins that bind various cell receptors ${ }^{39}$.

ZIKV-reported epidemics are related to specific social issues that include rapid urbanization in conditions of extreme poverty, intense deforestation that favors contact of populations with unknown vectors and pathogens, as well as the intensification of international travel and population mobility. These factors have provided the basis for the adaptation of vector survival and consequent changes in the transmission dynamics of this arbovirus, entering the human body during the transmission cycle $^{36,37}$.

Although ZIKV has already been isolated from different mosquitoes, $A$. aegypti remains the vector of transmission in Brazil and in various countries, the fact that the mosquito adapts to urban scenarios has contributed a lot in this sense $\mathrm{s}^{16,34,27,29}$.

Laboratory studies in China clearly demonstrated that, in addition to the Aedes species, the mosquito Culex pipiens quinquefasciatus has the potential to be a ZIKV vector ${ }^{53}$. However, in a study developed in the Brazilian Northeastern region, the most affected area by ZIKV, it was concluded that $C x$ quinquefasciatus should not be considered as a potential vector of ZIKV ${ }^{54}$. Thus, it is believed that there are still aspects related to ZIKV transmission that require further investigation, necessary to implement integrated epidemic prevention approaches.

It is estimated that the vector is capable of transmitting the virus with an extrinsic incubation period of approximately 10 days after artificial feeding. Then, mosquitoes can be infectious for up to 60 days after virus acquisition $^{37}$.

After the viremia period, symptomatic humans enter the convalescent stage and can no longer infect mosquitoes. Notably, those individuals remain infectious to other humans, although with reduced infectivity ${ }^{18}$. 

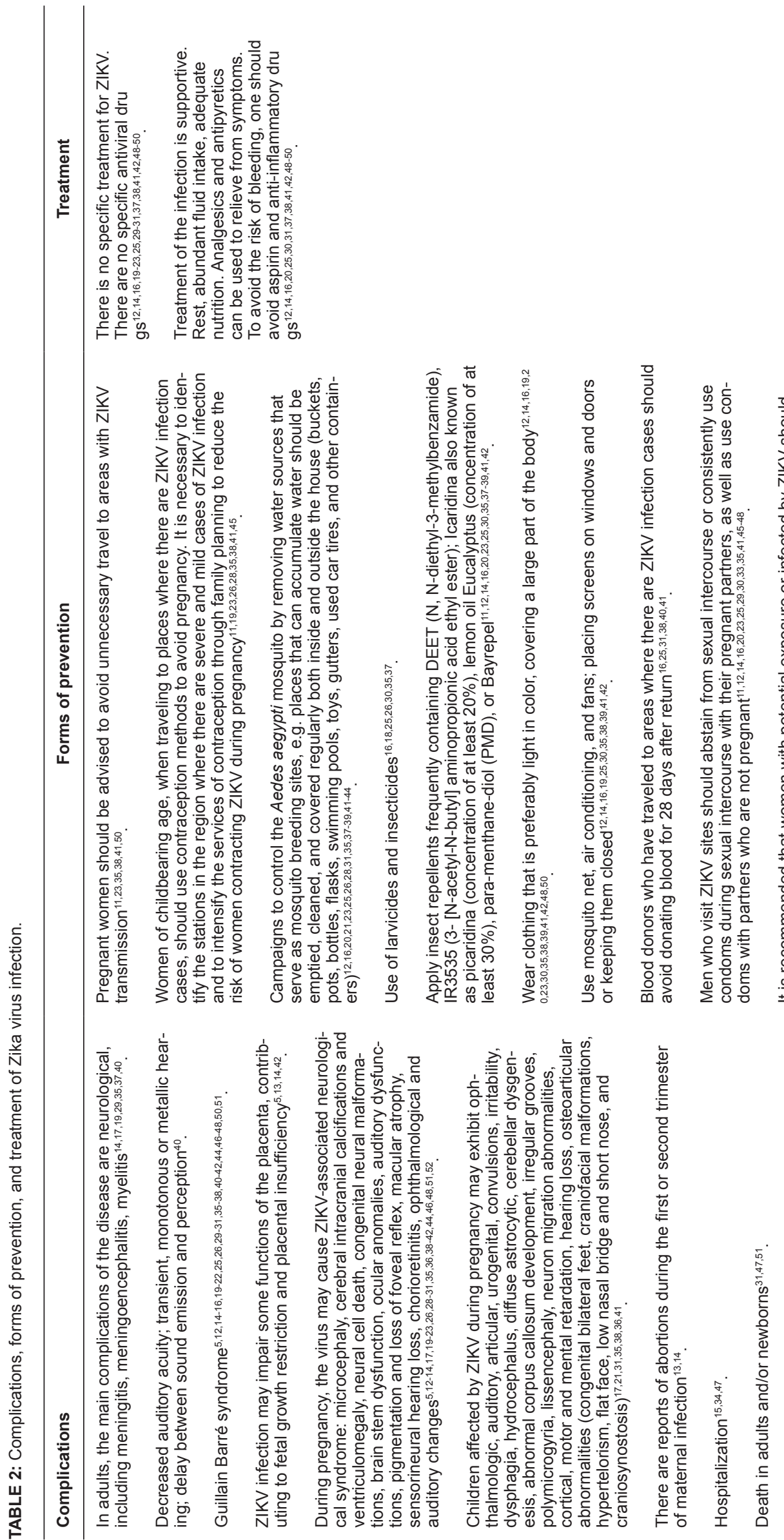
As shown in Table 1, there are various forms of ZIKV transmission. ZIKV can be sexually transmitted during intercourse for a broad period of time, before the onset of symptoms, in the symptomatic phase of the disease (when there is such) and after the resolution of symptoms. There are cases of sexual transmission of the virus between heterosexual men and women and vice versa ${ }^{17,24}$.

According to the evidence, the longest interval after the onset of symptoms during which sexual transmission can occur is 32-41 days. It is important to note that the detection of viral RNA in semen does not necessarily suggest that the virus will be transmitted. RNA may be detected in the semen of infected individuals up to 93 days after the onset of symptoms ${ }^{45}$.

The vertical transmission of ZIKV, i.e., when an infected pregnant woman transmits the disease to the fetus, has been a major public health concern because when the fetus is infected, the virus is capable of causing severe complications, such as the ZIKV congenital syndrome, as shown in Table 2.

Although ZIKV has already been identified in the saliva, sweat, breast milk and tears, there is still no evidence that the concentrations found in these fluids are sufficient for transmission ${ }^{24,28,36,31,46,40}$.

It is emphasized that transmission through breast milk is unlikely. Therefore, it is recommended that mothers infected with ZIKV who reside in endemic areas should continue to breastfeed their infants ${ }^{13,21,26,30,38,41,46}$.

The symptoms of ZIKV infection are similar to other arboviruses transmitted by Aedes; therefore, clinical diagnosis alone is not sufficient to determine the disease. In addition, laboratory findings, including lymphopenia, hematospermia, transient leukopenia, mild neutropenia, thrombocytopenia, mild elevation of liver enzyme levels, and presence of inflammatory markers such as C-reactive protein, fibrinogen, and ferritin are also non-specific ${ }^{43,37,48}$.

Laboratory diagnosis of ZIKV infection is challenging; often, accurate laboratory diagnosis requires combination of serological data with virus detection by molecular methods. Laboratory diagnosis of ZIKV is primarily based on the detection of viral ribonucleic acid (RNA) from biological specimens, including the blood, saliva, urine, and semen, among other body fluids and tissues ${ }^{16,22,30,38}$. For persons with suspected ZIKV disease, a positive real-time reverse transcriptionpolymerase chain reaction (rRT-PCR) result confirms infection, while a negative one does not exclude infection. In these cases, immunoglobulin M (IgM) and neutralizing antibody testing can identify additional recent ZIKV infections ${ }^{55,56}$.

In the acute phase of the disease, during the first 5 days of symptoms, the virus can be detected in the blood (the viremic period); however, in other specimens, the virus can be detected for a longer period. Alternatively, laboratory diagnosis can be made through ZIKV-specific IgM antibodies detection by enzyme immunoassay, performed in serum samples collected at the beginning of symptoms (acute phase) and 14-21 days after the onset of symptoms (convalescent phase). In some cases, an IgM positive result should be confirmed with another more specific technique, such as Plaque Reduction Neutralization Test, performed by well-trained technicians in specialized laboratories ${ }^{55,56}$.

According to some references, rRT-PCR should not be performed particularly during the first 7 days of disease $\mathrm{e}^{19,30}$. Some authors recommend that rRT-PCR should be performed from serum samples within 1-3 days after the onset of symptoms, or that saliva or urine samples should be collected within the first 3-5 days after symptoms ${ }^{16}$. According to Marano et al. ${ }^{27}$, in the first 3-5 days after the onset of symptoms, the period of viremia of the disease would be the time that allows for the direct detection of the virus.

In previous studies, it was reported that viral RNA was detected up to 10 days after the onset of symptoms ${ }^{37}$. While others recommend detection of RNA in urine, it would be possible to detect RNA up to 3 weeks after the onset of symptoms, which is extremely advantageous and practical ${ }^{20}$.

Divergent information regarding detection time of $\operatorname{IgM}$ antibodies was also found. Some studies showed that virusspecific IgM may be detected from the third day of the disease infection ${ }^{26,29}$. In other studies, serum IgM is detectable approximately 5 days after the onset of symptoms ${ }^{37}$. Some studies showed that ZIKV-specific IgM antibodies are produced during the first week of disease and can be detected from the seventh day onward ${ }^{13}$. Other studies demonstrated that antibodies to ZIKV were detected from the eighth day after symptoms onset ${ }^{31}$.

The use of saliva samples increases the molecular detection rate of ZIKV and is particularly important for the diagnosis of ZIKV in children and newborns, whose blood is more difficult to collect ${ }^{26}$. Of note, negative ZIKV rRT-PCR results from blood samples do not rule out ZIKV infection, because the stage of viremia is short $\mathrm{t}^{20,31}$.

The Guillain Barré syndrome (GBS) has been one of the most worrying complications of ZIKV infection in adults. GBS is an autoimmune disease characterized by various degrees of weakness, sensory abnormalities and autonomic dysfunction resulting from injury of the peripheral nerve or nerve root, causing motor weakness and paralysis ${ }^{15}$. Paralysis or muscle weakness may last for days or weeks, but most patients recover properly ${ }^{43}$. In the most severe cases, however, total paralysis occurs, causing respiratory distress, swallowing disorders, and death ${ }^{40,22}$.

It was initially believed that there would be a risk of congenital Zika syndrome only when maternal infection occurred during the first trimester ${ }^{29}$. However, fetal anomalies were found in women infected with ZIKV at various weeks of gestation, indicating that all three trimesters are vulnerable ${ }^{28,35}$. A study in Brazil found cases of severe microcephaly associated with ZIKV in all stages of gestation ${ }^{36}$.

Treatment of ZIKV infection continues to be similar to other arboviruses with respect to improvement in complaints and reduction in complications. The accompanying rash can cause severe discomfort in some patients and may be controlled with antihistamines, although the efficacy of these drugs is unclear. 
The use of non-steroidal anti-inflammatory drugs (NSAIDs), especially aspirin (salicylates), is not recommended because of its association with bleeding events, especially in children under 12 years old, due to the risk of developing Reye's syndrome. Corticosteroids should be avoided due to unknown efficacy and adverse events ${ }^{16,37}$.

In view of the limitations of ZIKV infection treatment and the complications that the disease may cause, it is important to broaden and enhance prevention actions. The control of arboviruses is challenging in several countries for a long time. The emergence of an epidemic by a type of unknown virus signals how public policies should move forward concerning this challenge. In addition to the biological aspects of the mosquito and the virus, there are structural, sociocultural, and environmental issues that also represent major barriers to disease control ${ }^{30}$.

There is still no vaccine available for the prevention of ZIKV infection, although research is already underway ${ }^{14,23,25,30,34,35,30}$. A potential vaccine is already undergoing experimentation at an early stage, indicating that the estimated time for application in humans is undetermined. The use of chemical substances, such as larvicides and insecticides, which many health management agencies have used as public health strategies, has unfortunately presented limitations, such as increased mosquito resistance and environmental imbalances ${ }^{57}$.

Although the results showed evidence of prevention forms with emphasis on individual care, elimination of mosquito breeding sites, and use of physical barriers to protect against vector bites, among others presented in Table 2, most of the Brazilian population lives in poor areas without proper housing and basic sanitation. This suggests that the fight against arboviruses goes beyond individual care; it emphasizes on social issues of public policy.

Health promotion and surveillance programs should be improved and enforced in order to enhance the quality of indicators and the ability to respond to unexpected occurrences of new diseases. Environmental policies are also important in light of the dramatic changes in the environment that affect ecosystems and favor proliferation of vectors and the emergence of new infectious diseases ${ }^{36}$.

\section{Final considerations}

We conclude that the Aedes aegypti mosquito is the main vector of ZIKV. The virus can be identified in blood samples, urine, saliva and even in man's semen, with blood serology being the most common diagnostic practice. It is estimated that $20 \%$ of the patients are symptomatic and clinical manifestations are nonspecific.

ZIKV causes neurological complications, especially for children, who were infected during pregnancy and could trigger the ZIKV-associated neurological syndrome. Control of the mosquito lifecycle, by removing sites that may serve for vector reproduction purposes, is a collective priority for the prevention of ZIKV infection. Pregnant women of reproductive age should use barriers that would prohibit contacts with the transmitting vector.
ZIKV infection as an epidemic is associated with specific social conditions. The review pointed to evidence that will contribute to the planning and implementation of public policies on infrastructure, environment, health, social assistance and education as effective measures to prevent, control and improve care for this type of arbovirosis.

Because ZIKV infection is an emerging disease, the study presented some weaknesses regarding the investigated aspects, especially recommendations for prevention sexual and vertical transmission. Another limitation in the search was that only one data source was used and only studies available free-of-charge were included.

Further research is recommended, considering the elements considered fragilities in this research, in view of the scientific production of new evidences regarding the ZIKV.

\section{Acknowledgments}

We thank the Regional University of Cariri (URCA), an institution that provides continuous training and fosters research and extension activities.

\section{Conflict of interest}

The authors declare that there is no conflict of interest.

\section{REFERENCES}

1. Gourinat AC, O'Connor O, Calvez E, Goarant C, Dupont-Rouzeyrol M. Detection of Zika virus in urine. Emerg Infect Dis. 2015;21(1):84-6.

2. Zanluca C, Melo VCA, Mosimann ALP, Santos GIV, Santos CND, Luz K. First report of autochthonous transmission of Zika virus in Brazil. Rio de Janeiro, Mem Inst Oswaldo Cruz. 2015;110(4):569-72.

3. Dupont-Rouzeyrol M, O’Connor $\mathrm{O}$, Calvez E, Daurès M, John M, Grangeon JP, et al. Co-infection with Zika and dengue viruses in 2 patients, New Caledonia, 2014. Emerg Infect Dis. 2015;21(2):381-2.

4. Lopes N, Nozawa C, Linhares REC. Características gerais e epidemiologia dos arbovírus emergentes no Brasil. Rev Pan-Amaz Saude. 2014;5(3):55-64.

5. Boeuf P, Drummer HE, Richards JS, Scoullar MJL, Beeson JG. The global threat of Zika virus to pregnancy: epidemiology, clinical perspectives, mechanisms, and impact. BMC Medicine. 2016;14(1):112.

6. Fauci AS, Morens DM. Zika virus in the Americas - yet another arbovirus threat. N Engl J Med. 2016;7(374):601-4.

7. Musso D, Nilles EJ, Cao-Lormeau VM. Rapid spread of emerging Zika virus in the Pacific area. Clin Microbiol Infect. 2014;20(10):5956.

8. Soares CB, Hoga LAK, Peduzzi M, Sangaleti C, Yonekura T, Silva DRAD. Revisão integrativa: conceitos e métodos utilizados na enfermagem. Rev Esc Enferm USP. 2014;48(2):335-45.

9. Mendes KDS, Silveira RCC, Galvão CM. Revisão integrativa: método de pesquisa para a incorporação de evidências na saúde e na enfermagem. Texto Contexto Enferm. Florianópolis, 2008;17(4):758-64.

10. Souza MT, Silva MD, Carvalho R. Integrative review: what is it? How to do it? Einstein. 2010;8(1):102-6.

11. Ahmad SSY, Amin TN, Ustianowski A. Zika virus: management of infection and risk. BMJ. 2016;352:11062. 
12. Borchardt RA. Zika virus: a rapidly emerging infectious disease. JAAPA. 2016,29(4):48-50.

13. Brito CAA, Cordeiro MT. One year after the Zika virus outbreak in Brazil: from hypotheses to evidence. Rev. Soc. Bras. Med. Trop. 2016;49(5):537-43.

14. de Carvalho NS, de Carvalho BF, Dóris B, Silverio Biscaia E, Arias Fugaça C, de Noronha L. Zika virus and pregnancy: an overview. Am J Reprod Immunol. 2017;77(2):1-8.

15. Dirlikov E, Kniss K, Major C, Thomas D, Virgen CA, Mayshack $\mathrm{M}$, et al. Guillain-Barré syndrome and healthcare Needs during Zika Virus Transmission, Puerto Rico, 2016. Emerg Infect Dis. 2017;23(1):134-6.

16. Fellner C. Zika Virus: anatomy of a Global Health Crisis. P\&T. 2016;41(4):242-53.

17. Fuwa K, Hayakawa S. Mechanisms and possible controls of the in utero Zika virus infection: Where is the Holy Grail? Am J Reprod Immunol. 2017;77(02):1-7.

18. Gao D, Lou Y, He D, Porco TC, Kuang Y, Chowell G, et al. Prevention and control of Zika as a mosquito-borne and sexually transmitted disease: a mathematical modeling analysis. Sci Rep. 2016;6:1-10.

19. Hajra A, Bandyopadhyay D, Heise LR, Bhadra R, Ball S, Hajra SK. Zika and pregnancy: A comprehensive review. Am J Reprod Immunol. 2017;77(2):1-7.

20. Hajra A, Bandyopadhyay D, Hajra SK. Zika virus: a global threat to humanity: a comprehensive review and current developments. $\mathrm{N}$ Am J Med Sci. 2016;8(3):123-8.

21. Hamel R, Liegeois F, Wichit S, Pompon J, Diop F, Talignani L, et al. Zika virus: epidemiology, clinical features and host-virus interactions. Microbes Infect. 2016;18:441-9.

22. Heukelbach J, Alencar C, Kelvin A, de Oliveira W, Pamplona de Góes Cavalcanti L. Zika virus outbreak in Brazil. J Infect Dev Ctries. 2016;10(2):116-20.

23. Jin J. Zika virus disease. JAMA. 2016;315(22):2373-82.

24. Kwak-Kim J, Song J, Kim MW, Gilman-Sachs A. Zika virus infection and biological treatment for reproductive medicine. Am J Reprod Immunol. 2017;77(2):1-5.

25. Laval F, Leparc-Goffart I, Meynard JB, Daubigny H, Simon F, Briolant S. Infections à virus Zika. Med Sante Trop. 2016;26(2): 145-50.

26. Lazear HM, Diamond MS. Zika virus: new clinical syndromes and its emergence in the western hemisphere. J Virol. 2016;90(10):4864-75.

27. Marano G, Pupella S, Vaglio S, Liumbruno GM, Grazzini G. Zika virus and the never-ending story of emerging pathogens and Transfusion Medicine. Blood Transfus. 2016;14:95-100.

28. Martinez ME. Preventing Zika Virus Infection during Pregnancy Using a Seasonal Window of Opportunity for Conception. PLoS Biology. 2016;14(7):1-11.

29. Mishra B, Behera B. The mysterious Zika virus: adding to the tropical flavivirus mayhem. J Postgrad Med. 2016;62(4):249-54.

30. Murray JS. Understanding Zika virus. J Spec Pediatr Nurs. 2017;22(1). doi: 10.1111/jspn.12164

31. Musso D, Gublerb DJ. Zika virus. Clin Microbiol Rev. 2016;29(3):487-524.

32. Olson CK, Iwamoto M, Perkins KM, Polen KND, Hageman J, Meaney-Delman D, et al. Preventing transmission of Zika virus in labor and delivery settings through implementation of standard precautions - United States, 2016. MMWR Morb Mortal Wkly Rep. 2016;65(11):290-2.
33. Oster AM, Brooks JT, Stryker JE, Kachur RE, Mead P, Pesik NT, et al. Interim Guidelines for Prevention of Sexual Transmission of Zika Virus - United States, 2016. MMWR Morb Mortal Wkly Rep. 2016;65(5):120-1.

34. Paixão EP, Barreto F, Teixeira MG, Costa, MCN, Rodrigues LC. History, epidemiology, and clinical manifestations of Zika: a systematic review. AJPH. 2016;106(4):606-12.

35. Petersen LR, Jamieson DJ, Powers AM, Honein MA. Zika virus. N Engl J Med. 2016;374(16):1552-63.

36. Possas C. Zika: what we do and do not know based on the experiences of Brazil. Epidemiol Health. 2016;38:e-2016023.

37. Salazar PM, Suy A, Sánchez-Montalvá A, Rodó C, Salvador F, Molina I. Zika fever. Enferm Infecc Microbiol Clin. 2016;34(4):247-52.

38. Sampathkumar P, Sanchez JL. Zika Virus in the Americas: A Review for Clinicians. Mayo Clin Proc. 2016;91(4):514-21.

39. Schuler-Faccini L, Ribeiro EM, Feitosa IML, Horovitz, DDG, Cavalcanti DP, Pessoa A, et al. Possível associação entre a infecção pelo vírus zika e a microcefalia - Brasil, 2015. MMWR Morb Mortal Wkly Rep. 2016;65(3):59-62.

40. Silva LRC, Souza AM. Zika virus: what do we know about the viral structure, mechanisms of transmission, and neurological outcomes? Rev Soc Bras Med Trop. 2016;49(3):267-73.

41. Slenczka W. Zika virus disease. Microbiol Spectrum. 2016;4(3):1019.

42. Toresdahl BG, Asif IM. Update on Zika virus: considerations for the traveling athlete. Sports Health. 2016;8(5):438-43.

43. Waggoner JJ, Pinsky BA. Zika virus: diagnostics for an emerging pandemic threat. J Clin Microbiol. 2016;54(4):860-7.

44. Faizan MI, Abdullah M, Ali S, Naqvi IH, Ahmed A, Parveen S. Zika virus-induced microcephaly and its possible molecular mechanism. Intervirology. 2016;59(3):152-8.

45. Brooks JT, Friedman A, Kachur RE, Laflam M, Peters PJ, Jamieson DJ. Update: Interim Guidance for Prevention of Sexual Transmission of Zika Virus - United States, July 2016. MMWR Morb Mortal Wkly Rep. 2016;65(29):745-7.

46. Baud D, Musso D, Vouga M, Alves MP, Vulliemoz N. Zika virus: a new threat to human reproduction. Am J Reprod Immunol. 2017;77(2). doi: 10.1111/aji.12614.

47. Walker WL, Lindsey NP, Lehman JA, Krow-Lucal ER, Rabe IB, Hills SL, et al. Zika virus disease cases - 50 states and the District of Columbia, January 1-July 31, 2016. MMWR Morb Mortal Wkly Rep. 2016;65(36):983-6.

48. Saiz J, Vázquez-Calvo A, Blázquez AB, Merino-Ramos $\mathrm{T}$, Escribano-Romero E, Martín-Acebes MA. Zika virus: the latest newcomer. Front Microbiol. 2016;7(496): doi: 10.3389/ fmicb.2016.00496.

49. Simões R, Buzzini R, Bernardo W, Cardoso F, Salomão A, Cerri $\mathrm{G}$, Zika virus infection and pregnancy. Rev Assoc Med Bras. 2016;62(2):108-15.

50. Macfadden DR, Bogoch II. Zika virus infection. CMAJ. 2016;188(5):311.

51. Paploski IAD, Prates APPB, Cardoso CW, Kikuti M, Silva MMOO, Waller LA, et al. Time lags between exanthematous illness attributed to Zika virus, Guillain-Barré syndrome, and microcephaly, Salvador, Brazil. Emerg Infect Dis. 2016;22(8):1438-44.

52. França GVA, Schuler-Faccini L, Oliveira WK, Henriques CMP, Carmo EH, Pedi VD, et al. Congenital Zika virus syndrome in Brazil: a case series of the first 1501 live births with complete investigation. Lancet. 2016;388(10047):891-7. 
53. Guo XX, Li CX, Deng YQ, Xing D, Liu QM, Wu Q,et al. Culex pipiens quinquefasciatus: a potential vector to transmit Zika vírus. Emerg Microbes Infect. 2016;5(9):e102.

54. Fernandes RS, Campos SS, Ribeiro PS, Raphael LMS, Bonaldo MC, Oliveira RL. Culex quinquefasciatus from areas with the highest incidence of microcephaly associated with Zika virus infections in the Northeast Region of Brazil are refractory to the virus. Mem Inst Oswaldo Cruz. 2017;112(8):577-9.

55. Rabe IB, Staples JE, Villanueva J, Hummel KB, Johnson JA, Rose L, et al. Interim Guidance for Interpretation of Zika Virus Antibody
Test Results. MMWR Morb Mortal Wkly Rep. 2016;65. doi: http:/ dx.doi.org/10.15585/mmwr.mm6521e1

56. Centers for Disease Control and Prevention (CDC). Revised diagnostic testing for Zika, chikungunya, and dengue viruses in US public health laboratories. Updated in February 7, 2016; cited Mai 30. Available from: http://www.cdc.gov/zika/pdfs/denvchikvzikvtesting-algorithm.pdf

57. Seley CM, González LJ, Tornese ML, Marchesi Olid LS, Martínez FN, Rossi ML, et al. Dengue and dengue haemorrhagic fever: its history and resurgence as a global public health problem: progress and challenges. Prensa Med Argent. 2009;96(7):395-406. 